\title{
Role of Public Relations in Corporate Image Building and Sustenance
}

\author{
Buike Oparaugo \\ buikeoparaugo@gmail.com \\ Mass Communication Department, The Polytechnic of Sokoto State, \\ Sokoto, Nigeria \\ https://doi.org/10.51137/ijarbm.2021.2.1.3
}

\begin{abstract}
Public relations (PR) is a strategic approach towards the creation of goodwill and brand image through developing a cordial relationship between the organization and its target audience. Image is the reputation or perception of a person, group or corporate body, held by others, often as a result of what they (the corporate body) do or have done. The study is set to find out two major things: To find out if PR plays a role in image building of an organization and to determine if PR plays a role in image sustenance of an organization. The methodology for the paper is the review of existing literatures in the field of PR and image building and sustenance. PR is identified as a veritable tool of corporate image building and sustenance as it helps shape the way publics of an organization see or perceive the organization. These publics can be internal or external. Internal refers e. g. to employees, and external refers e. g. to customers / clients and the society. In building or sustaining a corporate image of an organization by the Public Relations Officer, several important tools very can be identified, including press / news release, press / news conference, sponsorships, house organs, Annual General Meeting etc. Furthermore, different types of PR are presented.
\end{abstract}

Keywords - PR, Corporate Image, Media Relations, Marketing Communications, Press Release, Press Conference

\section{Introduction}

In any organization, the need to maintain the image of the organization is of great importance. No organization can satisfy its numerous public without being perceived first by the publics as trusted and dependable. The dependability of the organization depends on the degree of the comfort given to the publics and her goodwill.

It is widely accepted that the aim of any business organization is to achieve growth, increase in turn over, assets and profit. But all of this is dependent on the goodwill of the organization's various publics. Goodwill is secured not so much as a result of the organization's mere existence but as the sustained strategic planning, execution and evaluation of the perception of their publics in relation to the organization.

According to Pearson Education (2012) an organization's reputation, profitability, and its continued existence can depend on the degree to which its 
targeted public supports its goals and policies. PR specialists-also referred to as communication specialists and media specialists, among other titlesserve as advocates for clients seeking to build and maintain positive relationships with the public.

Effective PR can help manage reputation by communication and building good relationship with the organization stakeholders. PR is a discipline about reputation. The result of what you do. Say and what others say about you. In this interdependent world, it is really important for almost every kind of organizations to keep a long term and trustworthy relations with the communities or public in order to handle the up-coming challenges and also to maintain the survival and success.

The field of PR is also all about developing, understanding and building good relationship with the various publics including government, media, employees, investors, suppliers, customers etc. according to various researchers in the area of PR, it is a systematized effort in order to build the image and reputation of a business $n$ social context.

The worth of PR in any organization cannot be overlooked. This is largely dependent on the fact that PR unit of an organization is a crucial factor in deciding the success of any organization by developing and fostering its corporate image. Whether a company is "the hunter or the prey", a strong corporate image can have a profound impact on both short term financial results and long term corporate image.

PR department is saddled with the responsibility of maintaining mutual understandings between management, staffs and the public. It is also a strategic communication process that built beneficiary relationship between organizations and their publics. Corporate image refers to the overall reputation of an organization as determined by the various pictures, impression, knowledge, information and perceptions that the public's of that organizations have about it.

Relations with the media is the most obvious element in PR, so they form a tactical approachable to influence the opinions of others and change their behavior and creating new channels and opportunities for sale. However, as long as the PR built relationships with journalists working in areas that intersects with their work in order to spread news of their clients (Alhadid \& Qaddomi, 2016). Sustenance has to do with the maintaining of an organization's image for continued existence.

The corporate image of an organization forms a strong marketing communication and enhances public patronage. The results of this could encourage high patronage (Omale, 2007). The result of high productivity, improved sales of product (and services), fight competitive challenges, encourage employee relations, improve financial relations with customers and financial institutions, regulate relationships and minimize crises in organizations, increase public confidence that could encourage quality in staff recruitment (Ehikwe, 2005).

The study is set to find out two major things: To find out if PR plays a role in image building of an organization; and to determine if PR plays a role in image sustenance of an organization. The methodology for the paper is the 
review of existing literatures in the field of PR and image building and sustenance.

\section{Public Relations}

According to Nnamani (2016), the concept of PR is framed on the art and science of creating and maintaining mutual understanding and acceptance between human individuals, groups, organizations, companies, etc. PR is not mere words or talking without good deeds but rather deeds backed by well-packaged and timely words beamed at the right audience (Onyiaji, 2016). PR practice involves the need for research prior to initiating actions, careful planning and thorough evaluation or measurement of results (Chile, 2014a). PR is simply an apparatus for effective communication strategies in promoting marketing, relationships and building bridges of various organizational and their publics (Chile, 2014b).

$\mathrm{PR}$ is one of many communication-related disciplines undergoing radical changes today (Ukonu, 2013). PR is a top management function that helps achieve organizational objectives, define philosophy and facilitate organizational change (Oparaeke, 2012). PR are embedded in sustained programs and policies of mass marketing communications that contains rational messages and directed at the public of an organization with the prime interest and objective of balancing a plethora of dynamics evidence by lasting relationships and community spirit (Madu, 2010).

PR practice involves anticipating analyzing and interpreting public opinion, attitudes future trends and issues which might be relevant to any section of the corporate organization (Udeze et al., 2010).

PR is a strategic communication process that builds mutually beneficial relationships between organizations and their publics (Elliott, 2012).

PR can also be defined as the practice of managing communication between an organization and its publics (Grunig \& Hunt, 1984).

PR (PR) refer to the variety of activities conducted by a company to promote and protect the image of the company, its products and policies in the eyes of the public (Pranashree, 2019).

PR is a strategic approach towards the creation of goodwill and brand image through developing a cordial relationship between the organization and its target audience. Every organization exists in a social, legal, political environment where it has to interact with different agencies and individuals.

$\mathrm{PR}$ is the process of managing an organization's communications with stakeholders. This plays a reputation, compliance, marketing, risk and crisis management of a firm. PR may include activities that are built around a favorable company's image through publicity and public events.

\section{Corporate Image}

Image is the reputation or perception of a person, group or corporate body, held by others, often as a result of what they (the corporate body) do or have done (Oparaugo \& Salihu, 2019). According to Udeze, Okoro, and 
Agbo (2010) image is the totality of impressions people have about company, an individual, an organization. Corporate image is the immediate mental picture that audiences have of an organization. Corporate images can be fashioned more quickly through well-conceived communication programs.

Image, according to the Oxford Learner's Dictionaries (2021) is the impression that a person, an organization or a product, etc. gives to the public. Image is given so much consideration by managers of organizations because the people's opinions about an organization usually inform their disposition to such organization, its activities and products (Jolaso \& Adefolakan, 2014). That is why Dokunmu (2004) describes image as the picture, reflection or appearance of someone or something and the impression, perception, feeling or opinion these create in people's mind.

The impressive corporate reputation that gives birth to a healthy image, as a matter of necessity, must adopt the following basic principles posited by Byrnes (1999):

- $\quad$ Corporate Profile must have a good corporate profile and positioning to project the corporation.

- Corporate Policies, must be well defined to enable you know where to start on key issues and actions to take.

- Opens your gate, which allows the political world to see what is happening, explain problems, prospect and challenges.

- Communication: Corporate reputation requires good communication and use of the right communication tools.

For example: "See Paris and Die" is a deliberately coined message by the government of France to emphasize the beauty of its Capital City as reflected in their building structures of those periods in time and date.

A corporate image refers to how a corporation is perceived. It is a generally accepted image of what a company stands for. Typically, a corporate image is designed to be appealing to the public, so that the company can spark an interest among consumers, create share of mind, generate brand equity, and thus facilitate product sales.

A corporate image is not solely created by the company. Other contributors to a company's image could include news media, journals, labor unions, environmental organizations, and other NGOs. Corporations are not the only form of organization that create these types of images. Governments, charitable organizations, criminal organizations, religious organizations, political organization and educational organizations all tend to have a unique image, an image that is partially deliberated and partially accidental, partially selfcreated and partially exogenous.

The construction and maintenance of corporate image has been found critical to attracting, developing, and retaining an employer's talent pool. Individual career attachment decisions (e.g., seeking alternative employment, pursuing promotional opportunities) have been tied to public perceptions of a given organization. Corporate image is best viewed as a dynamic and continually evolving representation of an employer in the eyes of a diverse public. 


\section{$4 \quad$ Functions of PR}

PR specialized functions are categorized by the publics with which relationships are established, and to whom appeals are made to understand and/or accept certain policies, procedures, individuals, causes, products or services. Practitioners who perform specialized functions may play a management role, operate as a communications technician, or function in a dual role (Agility PR, 2013).

The major functions of PR are to create and maintain excellent relations with the organization's internal and external publics. These publics are the stakeholders of the organization and can be persons and private, governmental, and societal entities in general. PR can have a strong impact on public awareness at a much lower cost than advertising. PR functions are designed to help build trust and credibility with groups that are important to your organization. They help raise awareness about your organization as well as give it a chance to define, control and distribute its message to those both inside and outside your company. Effective PR functions can also promote your organization, help communicate during a crisis or defend its reputation from attacks people make on it in the media (Travis, 2018). However, the following are the functions of PR:

- Crisis management deals with emergencies affecting the organization. They help establish policies for dealing with emergencies, such as who gets to communicate with the media, and how management shares information with employees.

- Relationship management establishes strategies for building and maintaining relationships with important segments of the public such as customers and reporters.

- Image management professionals work to present the company as socially responsible, compassionate and involved in the community.

- Resource management looks at the budget and resources for the organization's PR and figures out how to make the best use of it.

An organization usually needs its PR team to fill more than one role. Managing relationships and shaping the company's image can generate a lot of goodwill. When a crisis or negative news breaks out, the PR role has to be the minimization of any damage or blowback from the events. In other words, damage control is what the head of the PR unit is set to do.

\section{Types of PR}

PR Department supervises and assesses public attitudes, and maintaining mutual relations and understanding between an organization and its public. It improves channels of communication and to institute new ways of setting up a two-way flow of information and understanding (Prince Muhammed Bin Fadden University, 2021). The following are the types of PR we have.

- Media Relations: Media relations is the process of establishing and maintaining an effective and cordial relationship between the press and 
an organization (Nworgu, 2002). For one, publicity material delivered through the media get what has been termed third party endorsement because the media add credibility to the message (Ukonu, 2013). Media relations is all about dealing with the media - writing press releases, scheduling interviews and giving press conferences. The goal is to generate positive coverage of your company or your product. Basically, you want the media to do your advertising for free (Bright Network, 2021).

- Investor Relations: Handling investor's events, releasing financial reports and regulatory filings, and handling investors, analysts and media queries and complaints.

- Government Relations: This means representing the brand to the government with regard to the fulfillment of policies like corporate social responsibility, fair competition, consumer protection, employee protection, etc. The foregoing was supported by Chile (2014a) when he writes that government relations means relating directly with legislature and regulatory agencies on behalf of the organization.

- Community Relations: Handling the social aspect of the brand and establishing a positive reputation in the social niche like environment protection, education, etc. Community relations is core of PR programming since it sends the tone of what an organization stands for - not in words (rhetoric) but in actions, i.e. behavior (F. U. Nnamani, 2019).

- Internal Relations: This is also known as employee relations. This however, means counseling the employees of the organization with regard to policies, course of action, organization's responsibility and their responsibility. It also means cooperating with them during special product launches and events. According to Ofor (2015), the employees run the organization. So, they must be informed on management's decisions, policies and activities.

- Customer Relations: Handling relationships with the target market and lead consumers. Conducting market research to know more about interests, attitudes, and priorities of the customers and crafting strategies to influence the same using earned media.

- Marketing Communications: Supporting marketing efforts relating to product launch, special campaigns, brand awareness, image, and positioning.

PR depending on who the target publics are. These target publics determine the type of PR to be used.

\section{Importance of PR}

PR is very important if organization-client relationship mist be maintained. The following are the importance of PR:

1. Increases Awareness: The company and the PR department primarily focus on spreading awareness by making people understand the product specifications and brand values.

2. Creates Brand Image and Reputation: The company has a chance to improve its image and build up a reputation among the public through PR practice.

Role of Public Relations in Corporate Image Building and Sustenance 
3. Develops Loyalty: The customers generate a loyalty factor for the brand because of an intense PR practice. They tend to buy from the company repeatedly.

4. Promotes Goodwill: In the long term, PR practice paves the way for creating substantial goodwill for the company.

5. Builds Trust and Credibility: The repetitive brand promotion, done in a way to align the company's objectives to those of the society and the target audience, develops trust and credibility among the public.

PR is expected to fulfill the above importance in order to help build and sustain an organization's image.

\section{$7 \quad$ PR Tools for Building Corporate Image}

In building corporate image, there are quite a number of tools that can be used. However, we are going to discuss a few important ones.

- Press Release: Part of a company's PR efforts includes putting a positive spin on news stories. A news story written by an organization to promote a product, service, or person. Consider how much better a story or a product recommendation is likely to be perceived when the receiver thinks the content is from an objective third party rather than an organization writing about itself.

- Press Conference: The Public Relations Officer (PRO) of the organization can call a press conference and speak to media personalities about the organization he represents. Both the press conference (news conference) and the press release (news release) can be pro-active or reactive. By being pro-active, the PRO does not wait for a problem to affect the image of the organization before speaking to the media. By being reactive, the PRO addresses the media or takes action when the organization has already been hit by an image problem.

- Sponsorship: An organization can sponsor a major program or event either on television or not, to help promote their image. Some of these events could be annual festivals, sports competitions, educational competitions, etc.

- House Organ: This is now known as in-house journal. It is in form of a magazine containing only information about an organization and their activities, possibly for the year or from a historical perspective or combined (both old and recent).

- Annual General Meeting (AGM): This is held yearly. The organization can choose any time of year to hold its AGM. It could be at the beginning of the year, middle of the year, end of the year, or any other time of the year. It is usually intended to discuss the prospects and challenges, strength and weakness, threats and opportunities of the organization.

- Customer / Client Relation: An organization from time to time, offers gifts to clients and customers. This is usually done at the beginning or at the end of the year, or at every major transaction. This can come in form of calendars, diaries, pens, etc. This act keeps a very long lasting memory of the company in the minds and thoughts of the customers / clients. 
These tools help PR officers to be effective in discharging their duties in time of building and maintaining relationships with both the external and internal publics while building and sustaining a corporate image.

\section{Conclusion}

The dependability of the organization depends on the degree of the comfort given to the publics and her goodwill. Goodwill is secured not so much as a result of the organization's mere existence but as the sustained strategic planning, execution and evaluation of the perception of their publics in relation to the organization.

The study is set to find out two major things: To find out if PR plays a role in image building of an organization; and to determine if PR plays a role in image sustenance of an organization. The methodology for the paper is the review of existing literatures in the field of PR and image building and sustenance.

PR is a strategic approach towards the creation of goodwill and brand image through developing a cordial relationship between the organization and its target audience.

Image has to do with the reputation or perception of a person, group or corporate body, held by others, often as a result of what they (the corporate body) do or have done; while a corporate image refers to how a corporation is perceived.

The major functions of PR are to create and maintain excellent relations with the organization's internal and external publics. There are seven types of PR. PR is very important if organization-client relationship mist be maintained. PR is expected to fulfill the above importance in order to help build and sustain an organization's image. In building corporate image, there are quite a number of tools that can be used.

The act of PR helps in building and sustaining a corporate image, as well as repairing an image. If not, organizations wouldn't be heavily on it. The approach adopted by the organization and its PRO also matters a lot. A proactive approach is better than a reactive approach, as the company may take time to repair an image, if at all it can be repaired $100 \%$.

\section{$9 \quad$ Authors}

Buike Oparaugo is a former lecturer at the Polytechnic of Sokoto State, Sokoto (now Umaru Ali Shinkafi Polytechnic, Sokoto) Nigeria. Oparaugo is a graduate of Mass Communication from the Institute of Management and Technology, Enugu, Nigeria. He has published textbooks in the field of mass communication as well as articles in journals in Nigeria. Oparaugo is currently an independent research consultant in Enugu, Nigeria. Oparaugo's interests are: advertising, PR, and media and politics. 


\section{References}

Agility PR. (2013, March 13). Public Relations Functions. Agility PR Solutions. $\quad$ https://www.agilitypr.com/resources/pr-glossary/publicrelations-specialized-functions/

Alhadid, A. Y., \& Qaddomi, B. A. (2016). The Role of Public Relations on Company Image: Social Media as a Moderating Variable: A Case Study at the Applied Science Private University at Jordan. International Journal of Academic Research in Business and Social Sciences, $6(4)$ 310-317 https://hrmars.com/papers/detail/IJARBSS/2109

Bright Network. (2021). A guide to the different types of PR. Bright Network;

Bright Network. https://www.brightnetwork.co.uk/career-pathguides/marketing-pr/different-types-pr/

Byrnes. (1999). Corporate reputation management and the environment: In critical issues in PR image-makers. Ogun NIPR Journal, 1.

Chile, D. N. (2014a). Aspects of public relations practice. Vast Publishers.

Chile, D. N. (2014b). Essentials of public relations and advertising research. Eagle Prints.

Dokunmu, O. (2004). The Image Question. Ogun NIPR Journal.

Ehikwe, A. E. (2005). Advertising and Other Promotional Strategies. Precision Publishers Ltd.

Elliott, S. (2012, March 2). Public Relations Defined, After an Energetic Public Discussion. The New York Times. 
https://www.nytimes.com/2012/03/02/business/media/publicrelations-a-topic-that-is-tricky-to-define.html

Grunig, J. E., \& Hunt, T. (1984). Managing Public Relations. Harcourt Brace Jovanovich.

Jolaso, B. A., \& Adefolakan, T. A. (2014). PR Architecture: An essential tool for corporate and business image. African Journal of Social Sciences,

95-103. https://www.sachajournals.com/user/image/ajss2014jolaos002.pdf

Madu, B. (2010). Public relations and media communications: Definition of public relations. In B. Madu (Ed.), Public Relations and Media Communications: African Perspectives. Immaculate Press.

Nnamani, F. U. (2019). Resolution of public relations cases in organizations: An integrated approach (2nd ed.). Enizol Ventures.

Nnamani, I. E. (2016). Fundamentals of public relations. Rhyce Kerex.

Nworgu, K. O. (2002). Public relations: Special issues and topics. Ultimate books.

Ofor, O. C. (2015). Public relations case study: Principles and application. Cath Comm Press.

Omale, J. A. (2007). Public relations and the corporate image (A study of United Bank for Africa and Intercontinental Bank PIC) [Master Thesis]. University of Nigeria.

Onyiaji, J. C. (2016). Fundamentals and practice of effective public relations. Archershoes Printing Press.

Oparaeke, G. C. (2012). Rudiments of public relations. Tropical Publishers. 
Oparaugo, B., \& Salihu, N. A. (2019). Corporate social responsibility: A veritable tool for corporate image-making and community development. The Beam: Journal of Arts \& Science, 12(1), 44-47. https://www.uaspolysok.edu.ng/thebeamjournal/articles.php?ids=vie $\underline{w \& j i d=255}$

Oxford Learner's Dictionaries. (2021). image noun—Definition, pictures, pronunciation and usage notes | Oxford Advanced Learner's Dictionary at OxfordLearnersDictionaries.com. In Oxford Learner's Dictionaries. Oxford University Press. https://www.oxfordlearnersdictionaries.com/definition/english/image? q=image

Pearson Education. (2012). What is Public Relations? Pearson Education. http://catalogue.pearsoned.ca/assets/hip/us/hip us pearsonhighere d/samplechapter/0205170005.pdf

Pranashree, S. (2019, September 14). What is Public Relations? - Meaning, Definitions, Objectives and Types. Economics Discussion. https://www.economicsdiscussion.net/marketing-management/whatis-public-relations $/ 31834$

Prince Muhammed Bin Fadden University. (2021). Functions of Public Relations. Prince Muhammed Bin Fadden University. https://www.pmu.edu.sa/about/functions pr

Travis, E. (2018). What Are the Functions of Public Relations? Bizfluent. https://bizfluent.com/about-7538233-functions-public-relations.html 
Udeze, S., Okoro, N., \& Agbo, B. (2010). Public relations practice: A functional approach. John Jacob's Publishers.

Ukonu, M. O. (2013). Excellence in Public Relations. Grand-Heritage Global Communications. 